[...........................

Consultation-Liaison Psychiatry in Japan 


\section{Advances in Psychosomatic Medicine}

\section{Vol. 23}

Series Editor

T.N. Wise Falls Church, Va.
Consulting Editors

H. Weiner Los Angeles, Calif.

L. Levi Stockholm

Editors

G.A. Fava Bologna

O.W. Hill London

I. Fukunishi Tokyo

G. Lloyd London

H. Freyberger Hannover

A. Reading Tampa, Fla.

F. Guggenheim Little Rock, Ark.

M. Hale New Britain, Conn.

P. Reich Boston, Mass.

M.B. Rosenthal Cleveland, Ohio 


\section{Consultation-Liaison Psychiatry in Japan}

Volume Editor

I. Fukunishi Tokyo

16 figures and 14 tables, 2001

KAR ER $\begin{aligned} & \text { Basel } \cdot \text { Freiburg } \cdot \text { Paris } \cdot \text { London } \cdot \text { New York } \cdot \\ & \text { New Delhi } \cdot \text { Bangkok } \cdot \text { Singapore } \cdot \text { Tokyo } \cdot \text { Sydney }\end{aligned}$ 


\section{Advances in Psychosomatic Medicine}

Founded 1960 by

F. Deutsch (Cambridge, Mass.)

A. Jores (Hamburg)

B. Stockvis (Leiden)

Continued 1972-1982 by

F. Reichsman (Brooklyn, N.Y.)

Library of Congress Cataloging-in-Publication Data

Consultation-liaison psychiatry in Japan / volume editor, I. Fukunishi.

p. ; cm. -- (Advances in psychosomatic medicine, ISSN 0065-3268; vol. 23)

Includes bibliographical references and index.

ISBN 3805572433 (hard cover : alk. paper)

1. Consultation-liaison psychiatry--Japan. I. Fukunishi, Isao. II. Series.

[DNLM: 1. Psychiatry--Japan. 2. Mental Disorders--therapy--Japan. 3.

Psychotherapy--methods--Japan. 4. Referral and Consultation--Japan. WM 100 C758 2001]

RC455.2.C65 C675 2001

$616.89^{\prime} 00952--d c 21$

2001037711

Bibliographic Indices. This publication is listed in bibliographic services, including Current Contents ${ }^{\circledR}$ and Index Medicus

Drug Dosage. The authors and the publisher have exerted every effort to ensure that drug selection and dosage set forth in this text are in accord with current recommendations and practice at the time of publication. However, in view of ongoing research, changes in government regulations, and the constant flow of information relating to drug therapy and drug reactions, the reader is urged to check the package insert for each drug for any change in indications and dosage and for added warnings and precautions. This is particularly important when the recommended agent is a new and/or infrequently employed drug.

All rights reserved. No part of this publication may be translated into other languages, reproduced or utilized in any form or by any means, electronic or mechanical, including photocopying, recording, microcopying, or by any information storage and retrieval system, without permission in writing from the publisher.

(C) Copyright 2001 by S. Karger AG, P.O. Box, CH-4009 Basel (Switzerland)

www.karger.com

Printed in Switzerland on acid-free paper by Reinhardt Druck, Basel

ISSN 0065-3268

ISBN 3-8055-7243-3 


\section{Contents}

VII Preface

1 General Concepts of Consultation-Liaison Psychiatry in Japan Kurosawa, H. (Chiba); Hosaka, T. (Kanagawa)

17 Psychooncology in Japan

Hosaka, T. (Kanagawa)

37 Psychonephrology in Japan

Haruki, S. (Tokyo)

58 Transplant Psychiatry in Japan

Fukunishi, I. (Tokyo); Surman, O.S. (Boston, Mass.)

85 Psychiatric Problems of Patients with HIVIAIDS in Japan

Hirabayashi, N.; Fukunishi, I. (Tokyo)

107 Drug-Induced Psychosis in Japan

Horikawa, N. (Tokyo)

119 Diabetes mellitus as So-Called Psychosomatic Disease in Japan Akimoto, M.; Fukunishi, I. (Tokyo)

128 Subject Index 


\section{Preface}

No longer can psychiatry be sequested in isolated asylums. With the development of psychiatric departments in medical schools and general hospitals it has been feasible to develop clinical units that focus upon the medically ill population. The subspecialty of psychiatry, commonly known as consultation-liaison psychiatry, provides the linkage between the issues that compromise psychological and biological health. Within Japan, consultation-liaison psychiatry has grown from a few brave pioneers to a dynamic group of many such physicians who work in medical settings and provide clinical care, teaching, and research to colleagues in other specialties of medicine. It is with great pride that this volume introduces the achievements of Japanese consultation psychiatry to a wider audience. I would like to thank Professor Thomas Wise and Mr. Steven Karger for the opportunity to publish this book.

The volume contains seven chapters that review basic issues in our field. The book begins with an historical overview of consultation-liaison psychiatry in Japan and attends to the present situation of the subspecialty. The role of psychiatry within oncology and renal medicine follows. The next chapter discusses psychiatric issues in organ transplantation. The problems of living with HIV/AIDS is the next contribution. The role of medications in inducing psychiatric disorders is presented and the book concludes with a chapter discussing psychological issues in diabetes. These papers are not only germane to Japan but will provide information that is useful to physicians throughout the world. Psychological distress in the medically ill is a universal phenomena. It is a reaction that defines us as human beings who exist in a biopsychosocial matrix. Within that context, consultationliaison psychiatry and its focus is truly an international medical subspecialty. 